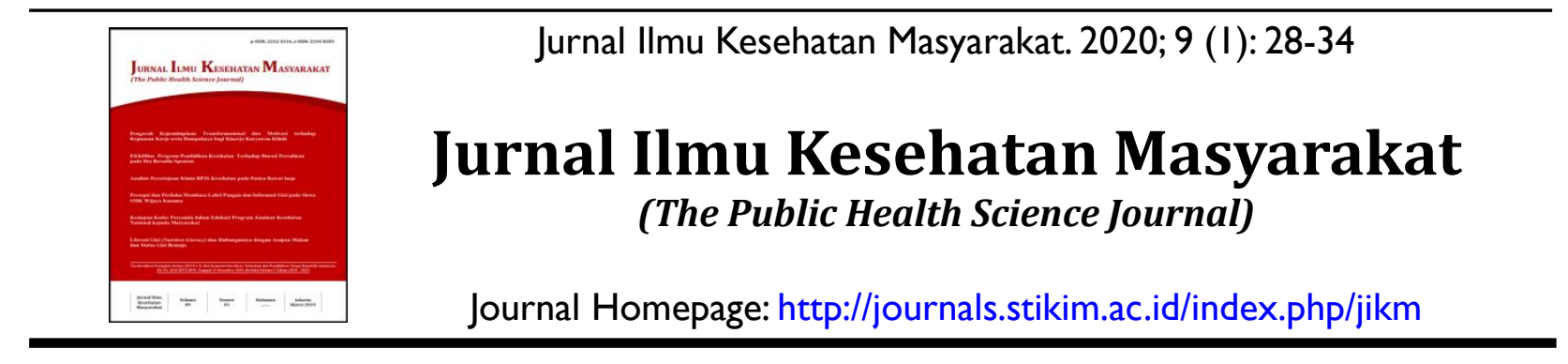

\title{
Efek Kepuasan Pasien terhadap Sisa Makan pada Pasien dengan Diet Lunak
}

\author{
Syabilila Indraswari ${ }^{1}$, Endang L. Achadi ${ }^{2}$, Mutiara $^{3}$ \\ ${ }^{1,2}$ Departemen Gizi Kesehatan Masyarakat, Fakultas Kesehatan Masyarakat, Universitas Indonesia \\ Jl. Lingkar Kampus Raya Universitas Indonesia, Kota Depok Jawa Barat, \\ ${ }^{3}$ RSU Adhyaksa Kejaksaan Agung RI, Jl. Mabes Hankam No. 60, Cipayung, Jakarta Timur \\ Email: ${ }^{1}$ syabilila.indraswari@gmail.com, ${ }^{2}$ endang.achadi@gmail.com, ${ }^{3}$ gizirsuadhyaksa@gmail.com
}

\begin{abstract}
Abstrak
Intake makan dan tingkat kepuasan pasien rawat inap merupakan isu yang penting di Rumah Sakit. Rendahnya intake makanan berpengaruh pada status gizi pasien rawat inap. Intake makan dan tingkat kepuasan paseien rawat inap dapat dilihat dari sisa makan. Penelitian ini mempelajari tentang efek kepuasan pelanggan terhadap sisa makan. Data yang digunakan merupakan data sekunder yang dikumpulkan oleh unit humas dan instalasi gizi RSU Adhyaksa. Penelitian ini merupakan penelitian dengan desain cross-sectional. Data kepuasan pelanggan dikumpulkan melalui kuesioner yang diisi oleh pasien, sedangkan data sisa makan makan diperoleh dengan cara observasi menggunakan metode comstock. Pasien yang berpartisipasi dalan penelitian ini sebanyak 486. Rata rata sisa makan responden sebesar $24,64 \%$ dan hanya $8,74 \%$ pasien yang menghabiskan makanannya. Hasil analisis bivariat menunjukkan bahwa kepuasan responden terhadap penampilan makanan $(\mathrm{Pv}=0,036 ; \mathrm{OR}=1,570)$ dan rasa makanan $(\mathrm{Pv}=0,009 ; \mathrm{O}=1,686)$ berhubungan dengan sisa makan. Hasil analisis multivariat menunjukkan bahwa variabel yang paling dominan mempengaruhi sisa makan adalah kepuasan terhadap rasa makanan ( $p$-value $=0,003 \mathrm{OR}=I, 785$ ). Penyelenggaraan makanan rumah sakit harus diperbaiki untuk memastikan pasien merasa puas dan menghabiskan makanannya.
\end{abstract}

Kata Kunci : Kepuasan pasien, rumah sakit, sisa makan

\begin{abstract}
Inadequate intake and level of satisfaction of inpatients is an important issue in hospital settings. Inadequate intake may influence nutritional status of inpatients. Inadequate intake and level of satisfaction are often indicated by leftovers. This research studies the effect of patient satsfaction on leftovers. Data of 486 inpatients was collected by public relation departement and nutrition departement of RSU Adhyaksa. This research using a cross-sectional study. Patients were asked to complete a patient satisfaction questionere and data leftovers was obtained using comstock methods. A total of 486 patients participated in this research. Average leftovers was $24,64 \%$ and only $8,74 \%$ of patients finished all the food. The result also indicated that satisfaction of food appearance $(P v=0,036 ; O R=1,570)$ and food taste are significantly related to plate waste $(P v=0,009 ; O R=I, 686)$. The result of multivariate indicated that satisfaction of food taste is the most dominant variabel $(p$-value $=0,003 \quad 0 R=I, 785)$ The hospital food service must be impoved to ensure that patient are satisfied and will consume hospital food.

Keywords: Patient Satisfaction, Hospital, Leftovers
\end{abstract}




\section{Pendahuluan}

Hospital malnutrition merupakan malnutrisi yang terjadi selama pasien dirawat di rumah sakit. Hospital malnutrition merupakan masalah yang kompleks dan dinamis yang akan berdampak buruk terhadap proses penyembuhan penyakit, selain itu pasien yang mengalami hospital malnutrition akan mempunyai resiko kekambuhan yang signifikan yang secara langsung maupun tidak langsung mempengaruhi morbiditas, lama hari rawat, menurunkan kualitas hidup dan mortalitas pasien rawat inap rumah sakit. Prevalensi hospital malnutrition sendiri dilaporkan berkisar antara 20\%-50\%, dan prevalensi di negara berkembang dilaporkan lebih tinggi daripada negara maju. ${ }^{1,2}$ Sedangkan penelitian lain menunjukkan bahwa diperkirakan $66,3 \%$ pasien yang dirawat di rumah sakit menderita malnutrisi atau mempunyai resiko tinggi menderita malnutrisi saat dirawat. ${ }^{3}$

Terdapat banyak penyebab tingginya angka hospital malnutrition, diantaranya penyakit pasien itu sendiri yang mengganggu penyerapan dan metabolisme zat gizi dalam makanan melalui berbagai macam mekanisme, serta asupan zat gizi yang tidak memadai saat dirawat. ${ }^{1}$ Makanan merupakan bagian intergral dan penting dalam terapi pasien di rumah sakit, tercukupinya kebutuhan nutrisi pasien selama dirawat dapat membantu meningkatkan proses penyembuhan pasien, mengurangi lama hari rawat yang berdampak pula pada pembiayaan., ${ }^{4,5}$

Limbah makanan telah menjadi masalah yang menjadi perhatian dunia, limbah makanan yang paling dikhawatirkan di rumah sakit adalah limbah sisa makan pasien. Beberapa penelitian menunjukkan bahwa, sisa makan telah menyumbang hingga $50 \%$ dari seluruh limbah yang dihasilkan suatu rumah sakit. Sisa makan yang tinggi dikaitkan dengan asupan energi dan protein serta zat gizi lain yang tidak memadai yang dapat mengakibatkan pasien rawat inap jatuh dalam kondisi malnutrisi, bisa dikatakan bahwa sisa makan merupakan indikator awal terjadinya malnutrisi. ${ }^{4,6}$

Tujuan pelayanan gizi rumah sakit adalah untuk memberikan makanan yang aman, higienis serta memenuhi kebutuhan pasien sehingga pasien dapat membantu pemulihan pasien, oleh karena itu pelayanan gizi rumah sakit harus mampu menciptakan makanan pasien yang hemat biaya, bergizi, serta memiliki daya terima yang besar sehingga meminimalisir sisa makan. Audit sisa makanan penting dilakukan untuk memastikan apakah makanan yang diberikan diterima dengan baik dan dikonsimsi oleh pasien. Audit sisa makan memberikan informasi yang dapat dijadikan sebagai acuan untuk memandu mengoptimalkan zat gizi yang dikonsumsi oleh pasien sekaligus meminimalkan pemborosan biaya yang dikeluarkan rumah sakit. $^{7}$

Pada tahun 2019 rata rata sisa makan pasien dengan diit lunak di RSU Adhyaksa tahun 2019 sebesar 24,64\%. Nilai ini diatas standar pelayanan minimal yang telah ditetapkan oleh Kementrian Kesehatan melalui Keputusan Mentri kesehatan Republik Indonesia Nomor 129/Menkes/SK/II/2008 tentang Standar Pelayanan Minimal Rumah sakit sebesar $\leq 20 \%$. Berdasarkan latar belakang tersebut, peneliti tertarik untuk melakukan analisis terhadap sisa makan dan kepuasan terhadap makanan yang disajikan pada pasien rawat inap dengan diit lunak diit lunak di RSU Adhyaksa Kejaksaan Agung RI. Tujuan dari penelitian ini secara umum adalah untuk menganalis efek tingkat kepuasan terhadap makanan yang disajikan dan hubungannya dengan sisa makan pasien pada pasien diit lunak di instalasi rawat inap RSU Adhyaksa Kejaksaan Agung RI.

\section{Metodologi}

Desain penelitian yang digunakan adalah cross-sectional. Sampel penelitian sebesar 486 pasien rawat inap RSU Adhyakasa Kejaksaan Agung RI yang mendapatkan diit lunak dalam rentang waktu Januari-Desember 2019. 
Pengambilan sampel dilakukan dengan cara acak sederhana dengan menggunakan rumus perhitungan besar sampel untuk uji hipotesis beda proporsi dengan derajat kemaknaan $95 \%$ dan kekuatan uji 90\%. Penelitian ini menggunakan data sekunder yang berasal dari laporan tahunan Instalasi Gizi RSU Adhyaksa tahun 2019 tentang sisa makan pasien dan laporan bulanan Humas RSU Adhyaksa tentang kepuasan pelanggan. Data sisa makan pasien dikumpulkan melalui pengamatan langsung secara visual dan dikategorikan menggunakan skala Comstock,

Kemudian menjadi dua yaitu $\leq 20 \%$ dan $>20 \%$. Data kepuasan pelanggan dikumpulkan oleh bagian humas rumah sakit dengan menggunakan kuesioner yang diisi oleh pasien saat akan pulang. Data kepuasan pelanggan meliputi penampilan makanan, kebersihan alat makan, variasi menu makanan dan rasa makanan yang kemudian dikategorikan menjadi 2 yaitu tidak puas (nilai 0-70) dan puas (nilai 71-100).

Analisis data dilakukan secara univariat, bivariat dan multivariat. Anaisis univariat dilakukan pada semua variabel penelitian untuk mengetahui sebaran dan gambaran setiap variabel. Analisis bivariat dilakukan dengan menggunakan uji statistik chi-square untuk mengetahui hubungan masing masing variabel independen terhadap variabel dependen. Sedangkan untuk mengetahui variabel yang paling berpengaruh terhadap variabel dependen digunakan uji multivariat regresi logistik berganda dengan tingkat kepercayaan $95 \%$.

\section{Hasil}

Jumlah responden yang dianalisis sebanyak 486 responden. Sebagian besar responden $(55,1 \%)$ berjenis kelamin perempuan (Tabel 1). Hasil observasi menunjukkan bahwa adalah hanya 46 $(9,46 \%)$ yang mempunyai sisa makan $0 \%$ atau tidak bersisa, artinya semua pasien meninggalkan sisa makanan. Hasil analisis univariat pada kepuasan pelanggan menyatakan sebagian besar responden $(97,9 \%)$ puas terhadap kebersihan alat makan, $70,6 \%$ responden menyatakan puas dengan penampilan makanan, $89,1 \%$ responden menyatakan puas terhadap variasi menu makanan, dan 62,1\% menyatakan puas terhadap rasa makanan (tabel 1). Sebagian besar responden $(57,4 \%)$ mempunyai total sisa makan diatas $20 \%$, dengan rincian rata-rata sisa makan makanan pokok sebesar 41,96\%, lauk hewani sebesar $14,71 \%$, lauk nabati sebesar $23,87 \%$, sayur sebesar $19,04 \%$ dan buah sebesar 1,87\% (Tabel 2).

Tabel 1. Distribusi Responden Berdasarkan Jenis Kelamin, Sisa Makanan, dan Kepuasan Pasien terhadap Makanan

\begin{tabular}{clcc}
\hline \multicolumn{1}{c}{ Variabel } & Kategori & n & \% \\
\hline Jenis kelamin & Laki-Laki & 218 & 44,9 \\
& Perempuan & 268 & 55,1 \\
Sisa makan & $0 \%$ & 46 & 9,46 \\
& $>0 \%-20 \%$ & 161 & 33,13 \\
& $>20 \%$ & 279 & 57,4 \\
Kepuasan pasien & & & \\
Kebersihan & Puas & 476 & 97,9 \\
& Tidak puas & 10 & 2,1 \\
Penampilan & Puas & 343 & 70,6 \\
& Tidak puas & 143 & 29,4 \\
Variasi menu & Puas & 433 & 89,1 \\
& Tidak puas & 53 & 10,9 \\
Rasa & Puas & 302 & 62,1 \\
& Tidak puas & 184 & 37,9 \\
\hline
\end{tabular}

Tabel 2. Rata-rata Sisa Makan Berdasarkan Jenis Hidangan

\begin{tabular}{lcc}
\hline \multicolumn{1}{c}{ Hidangan } & Rata-rata (\%) & SD (\%) \\
\hline Makanan Pokok & 41,96 & 41,51 \\
Lauk Hewani & 14,71 & 25,94 \\
Lauk Nabati & 23,87 & 27,3 \\
Sayur & 19,04 & 14,67 \\
Buah & 1,87 & 7,89 \\
\hline
\end{tabular}

Hasil analisis bivariat menunjukkan bahwa terdapat dua variabel yang berpengaruh signifikan ( $p$-value $<0,05$ ) terhadap sisa makan yaitu variabel penampilan makanan $(\mathrm{p}$-value $=0,036)$ dan rasa makanan $(\mathrm{p}$-value $=0,009)($ Tabel 3$)$.

Hasil analisis multivariat menggunakan regresi logistik berganda menunjukkan bahwa pada tahap seleksi 
bivariat dihasilkan satu variabel independen mempunyai $\mathrm{Pv}<0,25$ yaitu penampilan makanan $(\mathrm{Pv}=0,027)$ dan variabel rasa makanan $(\mathrm{Pv}=0,006)$. Dengan demikian variabel penampilan makanan dan rasa makanan masuk ke dalam pemodelan multivariat, sedangkan variabel kebersihan dan variasi makanan mempunyai nilai $P v \geq 0,25$ akan tetapi karena secara substansi penting maka dimasukkan ke dalam pemodelan multivariat (Tabel 4).

Tabel 3. Distribusi Sisa makan berdasarkan Variabel Kepuasan Pelanggan

\begin{tabular}{|c|c|c|c|c|c|c|c|}
\hline \multirow{3}{*}{ Variabel } & \multirow{3}{*}{ Kategori } & \multicolumn{4}{|c|}{ Sisa Makan } & \multirow{3}{*}{ P-Value } & \multirow{3}{*}{$\begin{array}{c}\text { OR } \\
(95 \% \mathrm{CI})\end{array}$} \\
\hline & & \multicolumn{2}{|c|}{$>20 \%$} & \multicolumn{2}{|c|}{$\leq \mathbf{2 0 \%}$} & & \\
\hline & & $\mathbf{n}$ & $\%$ & $\mathrm{n}$ & $\%$ & & \\
\hline \multirow[t]{2}{*}{ Kebersihan } & Tidak Puas & 5 & 50 & 5 & 50 & \multirow[b]{2}{*}{0,876} & 0,737 \\
\hline & Puas & 274 & 57,6 & 202 & 42,4 & & $(0,211-2,581)$ \\
\hline \multirow[t]{2}{*}{ Penampilan } & Tidak Puas & 93 & 65 & 50 & 35 & \multirow{2}{*}{$0,036^{*}$} & 1,570 \\
\hline & Puas & 186 & 54,2 & 157 & 45,8 & & $(1,048-2,352)$ \\
\hline \multirow{2}{*}{ Variasi menu } & Tidak Puas & 32 & 60,4 & 21 & 39,6 & \multirow[b]{2}{*}{0,752} & 1,147 \\
\hline & Puas & 247 & 57 & 186 & 43 & & $(0,641-2,054)$ \\
\hline \multirow[t]{2}{*}{ Rasa } & Tidak Puas & 120 & 65,2 & 64 & 34,8 & \multirow{2}{*}{$0,009^{*}$} & 1,686 \\
\hline & Puas & 159 & 52,6 & 143 & 47,4 & & $(1,155-2,462)$ \\
\hline
\end{tabular}

$*=$ Berhubungan secara statistik pada alpha $(\alpha) 0,05$

Tabel 4. Analisis Multivariat Tahap Seleksi Bivariat

\begin{tabular}{cc}
\cline { 2 - 2 } Variabel & p-value \\
\cline { 2 - 2 } Kebersihan Makanan & 0,634 \\
Penampilan Makanan & $0,027^{*}$ \\
Variasi Makanan & 0,642 \\
Rasa Makanan & $0,006^{*}$ \\
\cline { 2 - 2 } Berhubungan secara statistik pada alpha $(\alpha) 0,05$
\end{tabular}

Pada pemodelan multivariat didapatkan bahwa saat variabel kebersihan makanan dan variabel variasi makanan nilai OR variabel penampilan makanan dan rasa makanan berubah diatas $10 \%$ sehingga variabel kebersihan makanan dan variasi makanan dimasukkan kembali ke dalam pemodelan. Hasil pemodelan akhir multivariat didapatkan bahwa terdpat 2 variabel yang berhubungan dengan sisa makanan pasien yaitu penampilan makanan $(\mathrm{Pv}=0,017)$ dan rasa makanan $(\mathrm{Pv}=0,03)$ sedangkan variabel kebersihan makanan dan variasi makanan merupakan variabel confounding terhadap sisa makanan pasien (Tabel 4).

Variabel kepuasan terhadap penampilan makanan mempunyai $\mathrm{OR}=1,667$ yang berarti bahwa responden yang tidak puas terhadap penampilan makanan yang disajikan beresiko 1,667 kali lebih tinggi mempunyai sisa makan $>20 \%$ dibandingkan dengan responden yang puas terhadap penampilan makanan setelah dikontrol variabel kepusan terhadap kebersihan makanan dan variasi makanan. Variabel kepuasan terhadap rasa makanan mempunyai $\mathrm{OR}=1,785$ yang berarti bahwa responden yang tidak puas terhadap rasa makanan mempunyai resiko 1,785 kali lebih tinggi mempunyai sisa makan $>20 \%$ dibandingkan dengan responden yang puas terhadap rasa makanan setelah dikontrol variabel kepuasan terhadap kebersihan makanan dan variasi makanan (Tabel 5). Hasil analisis multivariat juga menunjukkan bahwa variabel yang paling dominan memengaruhi sisa makan adalah variabel kepuasan terhadap rasa makanan. 
Tabel 3. Pemodelan Akhir Multivariat

\begin{tabular}{lccc}
\hline \multicolumn{1}{c}{ Variabel } & Pvalue & OR & CI 95\% \\
\hline Kebersihan Makanan & 0,177 & 0,386 & $0,097-1,537$ \\
Penampilan Makanan & 0,017 & 1,667 & $1,096-2,534$ \\
Variasi Makanan & 0,807 & 1,082 & $0,573-2,043$ \\
Rasa Makanan & $0,003 *$ & 1,785 & $1,211-2,631$ \\
\hline \multicolumn{4}{c}{$*=$ Variabel paling dominan }
\end{tabular}

\section{Pembahasan}

Salah satu tujuan pelayaanan gizi dan makanan di rumah sakit adalah untuk menyediakan makanan berkualitas yang mendukung kebutuhan pasien akan zat gizi sehingga mempercepat proses penyembuhan Salah satu cara untuk melihat kebutuhan akan zat gizi terpenuhi atau tidak adalah dengan melihat sisa makan pasien. Tingginya sisa makan pasien erat kaitannya dengan kejadian hospital malnutrition, dan pemborosan biaya pada suatu rumah sakit.

Hasil penelitian sisa makanan di rumah sakit menunjukkan sisa makan sebesar $25-50 \%$, hasil ini jauh lebih tinggi daripada sisa makan di institusi lain yang menyediakan penyeleggaraan makanan. ${ }^{1,8}$ Berbagai penelitian menunjukkan bahwa sisa makan di restoran, kafe, kantin sekolah dan kantin tempat kerja dua sampai tiga kali lebih rendah dibandingkan jumlah sisa makan di rumah sakit, yaitu berkisar antara $15 \% .^{9,10}$ Tingginya sisa makan pasien mencerminkan bahwa asupan zat gizi pasien tidak memadai, padahal dukungan makanan sangat penting bagi pasien di rumah sakit untuk membantu proses penyembuhan, menurunkan angkan morbiditas, mortalitas dan lama hari rawat. Rata-rata sisa makanan pasien diit lunak di RSU Adhyakya Kejaksaan Agung RI sebesar 24,64\%. Angka ini tidak memenuhi standar pelayanan minimal yang telah ditetapkan oleh Kementrian Kesehatan sebesar $\leq 20 \%$, padahal sekitar $80 \%$ pasien RSU Adhyaksa memiliki diit lunak.

Sisa makan yang tertinggi pada penelitian ini adalah makanan pokok sebesar 42,19\%. Hasil penelitian ini sejalan dengan penelitian Manik, dimana presentase sisa makan yang paling tinggi adalah makanan pokok. ${ }^{11}$ Sisa makanan pokok yang besar dapat disebabkan makanan pokok kurang diminati dari segi rasa karena rasanya yang hambar, selain itu pasien rumah sakit mengalami penurunan indera perasa yang diakibatkan karena penyakit yang diderita .

Terdapat hubungan yang signifikan antara kepuasan responden terhadap penampilan dan rasa makanan terhadap sisa makan, dimana responden yang puas terhadap sisa makan dan rasa makanan memiliki sisa makan yang lebih sedikit dibandingkan dengan responden yang tidak puas terhadap penampilan dan rasa makanan. Penelitian McCrickerd menjelasakan bahwa penampilan makanan yang menarik mampu meningkatkan selera makan dan menurunkan jumlah sisa makan. ${ }^{12}$ Hasil penelitian ini sejalan dengan penelitian Wirasamadi dimana pasien yang menyatakan penampilan dan rasa makanan yang disajikan baik cenderung menyisakan sedikit sisa makanan. ${ }^{13}$ Penelitian ini mengukuhkan pendapat bahwa rasa pertama ada pada mata. Penampilan yang baik membuat pasien mengasumsikan bahwa makanan tersebut enak, dan pada akhirnya mau mencoba dan menghabiskan makanan yang disajikan.

Rasa makanan merupakan indikator yang bersifat sangat subjektif dan sulit dinilai secara akurat karena perbedaan selera setiap responden bersivat individual. Pada penelitian ini sebanyak sebagian besar pasien merasa puas terhadap rasa makanan namun ternyata hal ini masih terlalu rendah untuk meningkatkan sisa makan pasien oleh karena itu diperlukan perbaikan standar menu, standar resep dan standar bumbu agar kepuasan pasien terhadap rasa makanan dapat meningkat sehingga diharapkan sisa makan pasien menurun.

Pada penelitian ini sebagaian besar 
responden menyatakan puas terhadap penampilan makanan yang disajikan akan tetapi hal ini belum mampu menurunkan angka sisa makan pasien sesuai standar pelayanan minimal yang telah ditentukan. Penampilan makanan merupakan salah satu aspek penting dalam makanan, penampilan makanan yang baik akan mampu meningkatkan selera makan pasien yang kemudian memberikan dorongan kepada pasien untuk menghabiskan makanan. ${ }^{12}$

Pada penelitian ini kepuasan pasien terhadap kebersihan dan variasi makanan tidak berpengaruh secara signifikan terhadap sisa makanan. Sebagian besar responden merasa puas dengan kebersihan makanan dan variasi makanan akan tetapi sisa makan makan pasien masih tinggi. Hal ini dimungkinkan karena ada faktor lain yang menyebabkan sisa makan yang tinggi terutama kondisi fisiologis pasien serta lama rawat pasien yang menyebabkan pasien bosan dengan makanan rumah sakit. Hasil penelitian ini sejalan dengan penelitian Utami, yang menyatakan bahwa tidak ada hubungan yang signifikan antara sisa makan dan variasi makanan. ${ }^{14}$

Hasil uji multivariat menunjukkan bahwa variabel yang paling dominan mempengaruhi sisa makan adalah kepuasan terhadap rasa makanan. Responden yang menyatakan puas terhadap rasa makanan berpeluang mempunyai sisa makan yang lebih rendah dibandingkan dengan responden yang menyatakan tidak puas terhadap rasa makan. Cita rasa makanan yang baik menyebarkan bau yang menggugah selera dan rasa yang lezat sehingga merangsang indera penciuman dan indera perasa sehingga nafsu makan pasien meningkat yang pada akhirnya mempengaruhi sisa makan.

\section{Kesimpulan}

Faktor kepuasan pasien yang mempengaruhi sisa makanan di RSU Adhyaksa adalah kepuasan terhadap rasa makanan dan penampilan makanan. Sistem penyelenggaraan makanan RSU adhyaksa harus diperbaiki untuk memastikan pasien merasa puas dan menghabiskan makanannya. Perbaikan pada rasa makanan dan penampilan makanan penting untuk dilakukan akan meningkatkan kepuasan pasien dan berdampak pada menurunnya sisa makanan pasien. Turunnya sisa makanan bukan hanya berdampak pada tercapainya standar pelayan minimal, akan tetapi juga pada status kesehatan pasien, menurunnya lama rawat serta efisiensi anggaran pada rumah sakit tersebut.

\section{Ucapan Terima Kasih}

Ucapan terimakasih kasih penulis sampaikan kepada Direktur RSU Adhyaksa beserta jajarannya yang telah memberikan ijin dan dukungan dalam terselenggaranya penelitian ini.

\section{Daftar Pustaka}

1. Correia MITD, Perman MI, Waitzberg DL. Hospital Malnutrition in Latin America: A Systematic Review. J Clin Nutr. 2017;36(4):958-67.

2. Kemenkes RI. Pedoman Gizi Rumah Sakit. Jakarta: Kemenkes RI; 2013.

3. Koroušić Seljak B, Mlakar Mastnak D, Mrevlje $\check{Z}$, Veninšek G, Rotovnik Kozjek N. A Multi-center Survey on Hospital Malnutrition and Cachexia in Slovenia. Eur J Clin Nutr. 2019;

4. TAMBY CHIK C, Zulkiply N, Bachok S, Mohi Z, Shahril A. Plate Waste in Public Hospitals Foodservice Management in Selangor, Malaysia. Indian J Sci Technol. 2019 Jan 15;11:1-5.

5. García-Romero A, Escribano Á, Tribó JA. The Impact of Health Research on Length of Stay in Spanish Public Hospitals. Res Policy. 2017;46(3):591-604.

6. Simzari K, Vahabzadeh D, Saeidlou S, Khoshbin S, Bektaş Y. Food Intake, Plate Waste and Its Association With Malnutrition in Hospitalized Patients. Nutr Hosp. 2017 Nov 16;34:1376-81.

7. Ramesh S. Importance of Plate Waste Assessment in a Hospital Kitchen. Int J Adv Res. 2018;4(2):611-3.

8. Zaid ZA, Lim V, Chiann C, Jamhuri N. Plate Wastage Among Hospitalized Cancer Patients. Malaysian J Med Heal Sci. 2019;15(SP1):2636-9346.

9. Carvalho KP de, Martins FP de O, Custódio IDD, Santos EDN, Souza DNP de, Maia YC de P. Effect of the implementation of the mixed cafeteria system in a Hospital Nutrition and 
Dietetic Service. Nutr Hosp. 2017;34(5):11707.

10. Kinasz TR, Reis RB, Morais TB. Presentation of a Validated Checklist as a Tool for Assessing, Preventing and Managing Food Waste in Foodservices. Food Nutr Sci. 2015;06(11):98591.

11. Manik LK, Hermansyah A, Puspita WL, Gizi J, Pontianak PK. Pengaruh Konseling Gizi Menggunakan Media Leaflet Terhadap Perubahan Sisa Makan Pasien Rawat Inap Kelas III di RSUD Soedarso Pontianak. Pontianak Nutr J. 2019;2 (1):11-4.
12. Mccrickerd K, Forde CG. Sensory Influences on Food Intake Control: Moving Beyond Palatability. Obes Rev. 2016;17(1):18-29.

13. Wirasamadi NLP, Adhi KT, Weta IW, Wirasamadi NLP, Adhi KT, Weta IW, et al. Analisis Sisa Makanan Pasien Rawat Inap di RSUP Sanglah Denpasar Provinsi Bali. Public Heal Prev Med Arch. 2015;3(1):88-95.

14. Utami NPA, Mustika IG, Sulistyadewi N. Hubungan Variasi Menu dan Lama Rawat Terihadap Sisa Makan Diet Rendah Garam. In: Sintesa. Bali; 2019. p. 265-70. 